Calcium cystic fibrosis isoproterenol protein

\title{
The Chronically Reserpinized Rat as a Possible Model for Cystic Fibrosis. VI. Synergistic Effects of Isoproterenol on $\mathrm{Ca}^{++}$and Protein in the Submaxillary Gland
}

\author{
DOUGLAS L. WOOD AND J. RICARDO MIARTINEZZ"2) \\ Deparme'me of Child Healh, University of Missouri, School of Medicine, Columbia, Missouri, USA
}

\begin{abstract}
Summary
Elevated calcium and protein concentrations are a consistent abnormality in submaxillary saliva from patients with cystic fibrosis (CF) and from experimental animal models developed by the chronic administration of either isoproterenol (IPR) or reserpine. The possibility that the effects of the two drugs may be additive was investigated by assessing their combined effects on glandular and salivary $\mathrm{Ca}^{++}$and protein in the rat submaxillary gland. Individually, their effects were also assessed in relation to the dose used. Results indicate that: (I) treatment for 7 days with $0.05,0.50$, and $5.0 \mathrm{mg} / \mathrm{kg}$ daily doses of reserpine caused, respectively, a $45 \%, 95 \%$, and $120 \%$ increase in glandular $\mathrm{Ca}^{+}$ and a $9.3 \%, 16.5 \%$, and $37.4 \%$ increase in glandular protein; (2) treatment for 7 days with a $5.0 \mathrm{mg} / \mathrm{kg}$ daily dose of isoproterenol caused a $138 \%$ increase in gland $\mathrm{Ca}^{+}$and a $12.38 \%$ increase in gland protein. Treatment with a $5.0 \mathrm{mg} / \mathrm{rat}$ daily dose of this drug caused increases of $166 \%$ and $10.3 \%$ in gland Ca t and protein; (3) in experiments involving a combination of the two drugs, isoproterenol was administered in a $5.0 \mathrm{mg} / \mathrm{kg}$ daily dose from days $1-7$ and reserpine in a $0.5 \mathrm{mg} / \mathrm{kg}$ daily dose from days 4-10 of the treatment schedule. This procedure resulted in (a) a $217 \%$ increase in gland $\mathrm{Ca}^{++}$and a $25.7 \%$ increase in gland protein; (b) a marked accumulation of a granular, basophilic material in acinar cells and the development of intraductal precipitates; (c) the secretion of turbid saliva with high $\mathrm{Ca}^{++}$and protein concentrations after a secretory dose of isoproterenol (this type of stimulation also reduced the gland $\mathrm{Ca}^{++}(50 \%)$ and protein (20\%) contents and produced vacuolization in the acinar cells); (d) the secretion of saliva with elevated $\mathrm{Ca}^{++}$and protein in response to pilocarpine (these elevated concentrations were, however, one-fifth of those obtained after isoproterenol stimulation); (e) the secretion of smaller volumes of saliva after both types of stimulation. These findings indicate that both IPR and reserpine have a dose-related and significant effect on submaxillary gland $\mathrm{Ca}^{++}$and protein and that their individual effects are synergistic. The implications of this synergism for the physiologic state of the submaxillary gland and for the secretory abnormality of cystic fibrosis are discussed.
\end{abstract}

\section{Speculation}

Chronic administration of either isoproterenol or of reserpine to rats results in significant morphologic and secretory changes in the salivary glands, resembling those seen in cystic fibrosis. An important effect of the two drugs involves $\mathrm{Ca}^{++}$and protein, which are increased in the gland and saliva from the treated animals. Since a disturbance of $\mathrm{Ca}^{++}$and protein (glycoprotein) secretion seems to be a fundamental and consistent finding in the submaxillary gland of $C F$ patients, such drug effects on the rodent gland are of interest as they may contribute to our understanding of possible mechanisms underlying the $\mathrm{CF}$ abmormality. This is particularly so since the two drugs seem to affect salivary $\mathrm{Ca}^{++}$and protein through independent mechanisms, which raises the possibility that their effects may be synergistic under appropriate experimental conditions and result in an even greater disturbance of salivary $\mathrm{Ca}^{++}$and protein than that produced by either drug alone.

The chronic administration of either isoproterenol or reserpine (o) rats has been shown to induce significant morphologic and secrelory changes in the salivary glands, and both types of chronically treated animals have been proposed as experimental animal models for eystic fibrosis (15-17), a hereditary human discase that involves exocrine tissues and secretions (8). In the rat submaxillary gland, both drugs catuse an increase in glandular and salivary $\mathrm{Ca}^{++}$and protein contents (9, 10, 17, 18). Since a change in the protein (glycoprotein) and $\mathrm{Ca}^{++}$metabolism of the submaxillary gland appears to be a fundamental and consistent disturbance in cystic fibrosis $(2-4,6,12,14)$, the effects of isoproterenol and of reserpine on the ${ }^{(} a^{++}$and protein homeostasis of the rat submaxillary gland are of interest, particularly since the two drugs appear to induce changes through distinct and independent mechanisms. This raises the possibility, therefore, that their individual effects on protein and $\mathrm{Ca}^{+}$metabolism may be additive or synergistic under appropriate experimental conditions. This, in turn, maty contribute to our understanding of possible pathogenetic mechanisms operating in the ( $\mathrm{a}^{+}$and protein disturbance of the submaxillary gland of the CF patient. In this investigation we have studied, therefore, the individual and combined effects of isoproterenol and of reserpine on the rat submaxillary gland. Glandular composition has been determined at rest and affer stimulation with secretagogues in animals treated in a chronic fashion with: $(l)$ three different daily doses of reserpine; (2) two different daily doses of isoproterenol; and (.3) a combination of the two drugs in two different dosage schedules. In addition, the composition of saliva in the latter group of animals has been studied. Finally, the morphology of the gland in animals treated with a combination of the two drugs was studied in the resting (unstimulated) and poststimulation stittes.

\section{MII:THODS}

\section{EXPERINENTAL ANIMALS AND SCHFDUILS OF DRUG} ADMINISTRATION

Male adult rats of the Sprague-Dawley strain were used. The animals were divided into the following groups: group $l$, control animals which received no drugs but were housed in the same quarters for periods of time comparable to those used in the drug 
treatments; group 2, animals treated with reserpine for 7 days in the following daily dosages: $0.05,(0.5$, and $5.0 \mathrm{mg} / \mathrm{kg} ; \mathrm{group} .3$, animals treated with isoproterenol for 7 days in daily doses of 5 $\mathrm{mg} / \mathrm{kg}$ and $5 \mathrm{mg} / \mathrm{rat}$; group 4 , animals treated with a combination of reserpine and isoproterenol. In this group, the dose of reserpine was $0.5 \mathrm{mg} / \mathrm{kg}$-day and the dose of isoproterenol was either $5 \mathrm{mg} / \mathrm{kg}$ - day or $5 \mathrm{mg} / \mathrm{rat}$ - day. Administration of isoproterenol was started on day 1 of the treatment schedule and continued for 7 days. Administration of reserpine was started on dily 4 of the treatment schedule and also continued for 7 days. The two drugs were administered concomitantly, therefore, on days 4.5 , 6 , and 7 of the treatment period. Drugs were injected intraperitoneally after the rats had been weighed. The initial weight of the animals at the start of the different drug treatments was between 175 and $225 \mathrm{~g}$. The animals were housed in pairs and had free acess to food and water during the treatment period.

\section{GLAND HOMOGENATES}

Wet tissue composition was determined in the resting (unstimulated) submaxillary glands of all groups of animals by homogenization of the freshly excised and weighed tissues in $10 \mathrm{cc}$ icecold distilled water by using a Polytron homogenizer. The following analyses were performed on the gland homogenates: $(l)$ $\mathrm{Ca}^{++}$in a calcium analyzer from Corning Instruments (23); and (2) protein by the Lowry method (1.3). The percentage of water content and the dry tissue composition of the resting glands were also determined in animals treated with the $0.5-\mathrm{mg} / \mathrm{kg}$ dose of reserpine, with the two doses of isoproterenol $(5 \mathrm{mg} / \mathrm{kg}$ and 5 $\mathrm{mg} / \mathrm{rat}$ ) and with the combination of the two drugs. For this purpose, the glands were excised, weighed, and placed in a drying oven for $48 \mathrm{hr}$ at $90^{\circ}$. It was found that no additional water loss occurred after this time.

\section{STINULATION OF SALIVARY SECRETION}

Since salivary secretions have been well characterized previously in rats treated with isoproterenol $(9,19)$ and with a $0.5-$ $\mathrm{mg} / \mathrm{kg}$ dose of reserpine $(17,18)$, this investigation was concerned primarily with the composition of submaxillary saliva in animals treated with the combination of the two drugs. Salivary secretion wats stimulated in these animals with either pilocarpine nitrate ( $1 \mathrm{mg} / 100 \mathrm{~g}$ body weight) or isoproterenol sulfate (10 $\mathrm{mg} / \mathrm{rat}$ ). The animals were anesthetized by intraperitoneal injection of sodium pentobarbital $(8 \mathrm{mg} / 100 \mathrm{mg}$ body weight) $24 \mathrm{hr}$ after the last drug injection and hoth submaxillary glands were exposed through a neck incision. After tracheal intubation, the main excretory ducts were cannulated below the hilum with a short length of polyethylene tubing (Clay Adams PE 10). The tube was pulled over a microflame to obtain a tip diameter of $12(0-140 \mu \mathrm{m}$ and was inserted $0.3 \mathrm{~cm}$ into the lumen. No ligatures were used in order to prevent obstruction of flow. Salivary secretion was elicited by intraperitoneal injection of the secretagogues and the saliva extruded in the first 3 min was discarded, as it represents fluid that was present in the duct system before stimulation. After this time, saliva samples were collected in preweighed plastic microsample tubes, timing the collection period in order to obtain from $5(1)-100 \mu$ l for analyses. Collection of saliva proceceded in this fashion until no more fluid could be seen at the tip of the cannula. The collection tubes were reweighed when the experiment was completed to obtain a gravimetric estimation of the volumes of fluid in each sample. After secretion had terminated, the submaxillary glands were separated from the adjoining sublingual glands, excised, gently blotted, and weighed to the nearest milligram in a semimicro analytic balance. Rates of salivary flow were calculated in terms of wet gland weight. The glands was placed rapidly in 10 ec icecold distilled water and homogenized in a Polytron homogenizer. The homogenates and the saliva samples were analyzed for $\mathrm{Ca}^{++}$and protein as previously indicated.

\section{MORPIOLOGICAL SIUDIES}

Both resting and stimulated glands from animals treated with a combination of isoproterenol $(5 \mathrm{mg} / \mathrm{kg})$ and reserpine $(0.5 \mathrm{mg} /$ $\mathrm{kg}$ ) were excised in some experiments and immediately placed in $10 \%$ buffered formalin. The tissues were transferred 24 hr hater to $70 \%$ alcohol, embedded, cut, and stained with Alcian blueperiodic acid-Schiff stain or with toluidine blue.

\section{STATISTICAL ANALYSIS}

In experiments involving the composition of gland homogenates, means and standard deviations of the mean were calculated for each of the parameters studied. Comparison between mean values was made by using Student's t-test of statistical significance. A $P$ value of less than 0.05 was considered significant.

\section{RESULTS}

\section{COMPOSITION OF UNSTIMULATED SUBMAKILLARY (BLAND}

The wet tissue composition of the unstimulated submaxillary gland of the different groups of animals is illustrated in Table 1 . When compared to unstimulated control glands, the composition of the glands of drug-treated animals shows the following characteristics: (l) treatment with reserpine produces progressive increases in glandular $\mathrm{Ca}^{++}$and protein contents, which are significant $(P<0.005)$ at all three dosages of reserpine used. The increases in $\mathrm{Ca}^{++}$and protein content. furthermore. Were significantly different from each other at each successively higher bose of reserpine, which implies that the effect of reserpine on glandular $\mathrm{Ca}^{++}$and protein is dose-dependent: (2) treatment with isoproterenol results in a significant increase in $\mathrm{Ca}^{++}$and protein contents of the gland when these values are compared with those of control glands $(P<0.0(0.5) ;(3)$ treatment with a combination of IPR and reserpinc results in significant increases $(P<0.0(1.5)$ in glandular $\mathrm{Ca}^{++}$and in protein content. Further comparison of the data illustrated in Table 1 indicates the following: (1) the

Table 1. Calcium and protein contents of unstimulated submaxillary gland (wet tissuc)

\begin{tabular}{|c|c|c|c|c|}
\hline Treatment & $\begin{array}{l}\text { Daily } \\
\text { dose, } \\
\mathrm{mg} / \mathrm{kg}\end{array}$ & $n$ & $\begin{array}{c}\mathrm{Ca}^{++}, \mu \mathrm{g} / \mathrm{g} \\
\text { wet wt }\end{array}$ & $\begin{array}{c}\text { Protein, } \mu g / g \\
\text { wet wt }\end{array}$ \\
\hline None (controls) & & 18 & $\begin{aligned} & 0.3(01 \\
\pm & 0.0 .3()^{1}\end{aligned}$ & $\begin{array}{l}102.51 \\
\pm 6.87^{1}\end{array}$ \\
\hline \multirow[t]{3}{*}{ Reserpine } & 0.05 & 10 & $\begin{array}{r}0.4 .34 \\
\pm 0.050\end{array}$ & $\begin{array}{l}112.06 \\
\pm+.34\end{array}$ \\
\hline & 0.50 & 36 & $\begin{array}{r}0.586 \\
\pm 0.036\end{array}$ & $\begin{array}{l}119.45 \\
\pm 5.54\end{array}$ \\
\hline & $5.0(0$ & 10 & $\begin{array}{r}0.662 \\
\pm 0.030\end{array}$ & $\begin{array}{r}140.80 \\
\pm 9.30\end{array}$ \\
\hline \multirow[t]{2}{*}{ Isoproterenol } & 5.00 & 24 & $\begin{array}{r}0.717 \\
\pm 0.023\end{array}$ & $\begin{array}{l}115.20 \\
\pm 2.10\end{array}$ \\
\hline & $5.00)^{2}$ & 12 & $\begin{array}{r}0.800 \\
\pm 0.034\end{array}$ & $\begin{array}{r}113.00 \\
\pm 1.60\end{array}$ \\
\hline \multirow[t]{2}{*}{$\begin{array}{l}\text { Isoproterenol + re- } \\
\text { serpine }\end{array}$} & $\begin{array}{l}5.00 \\
+ \\
0.50\end{array}$ & 22 & $\begin{array}{r}0.954 \\
\pm 0.032\end{array}$ & $\begin{array}{l}128.80 \\
\pm 1.50\end{array}$ \\
\hline & $\begin{array}{l}5.00)^{2} \\
+ \\
0.50\end{array}$ & 12 & $\begin{array}{r}0.936 \\
\pm 0.074\end{array}$ & $\begin{array}{r}139.76 \\
\pm 2.511\end{array}$ \\
\hline
\end{tabular}

1 Values represent standard deviations of the mean.

"This corresponds to a dose of isoproterenol of $5 \mathrm{mg} / \mathrm{rat} \cdot$ day. 
able 2. Submaxillary gland weight, gland weight/body weight $3 W^{\prime} / B W$ ) ratios and percentage of water content (unstimulated glands)

\begin{tabular}{|c|c|c|c|c|}
\hline Treatment & Daily dose & $\begin{array}{c}\text { Gland } \\
\text { weight. } \\
\text { mg }\end{array}$ & $\begin{array}{l}\text { GW/IBW } \\
(\times 10(0)\end{array}$ & $\begin{array}{l}\text { Co Water } \\
\text { content }\end{array}$ \\
\hline ontrol & & $\begin{array}{l}208.6 \\
\pm 9.8\end{array}$ & $\begin{array}{r}83.89 \\
\pm 4.58\end{array}$ & $\begin{array}{l}77.45 \\
\pm 0.421\end{array}$ \\
\hline eserpine & $0.5 \mathrm{mg} / \mathrm{kg}$ & $\begin{array}{r}148.1 \\
\pm 7.0\end{array}$ & $\begin{array}{r}89.36 \\
\pm 3.66\end{array}$ & $\begin{array}{r}75.98 \\
\pm 0.34\end{array}$ \\
\hline oproterenol & $\begin{array}{l}5.0 \mathrm{mg} / \mathrm{kg} \\
5.0 \mathrm{mg} / \mathrm{rat}\end{array}$ & $\begin{array}{r}289.7 \\
\pm 12.6 \\
323.9 \\
\pm 13.5\end{array}$ & $\begin{array}{r}124.39 \\
\pm 5.35 \\
143.97 \\
\pm 7.01\end{array}$ & $\begin{array}{r}74.39 \\
\pm 0.23 \\
73.53 \\
\pm 0.22\end{array}$ \\
\hline \multirow[t]{2}{*}{$\begin{array}{l}\text { ioproterenol + re- } \\
\text { serpine }\end{array}$} & $\begin{array}{c}5.0 \mathrm{mg} / \mathrm{kg} \\
+ \\
0.5 \mathrm{mg} / \mathrm{kg}\end{array}$ & $\begin{array}{r}240.2 \\
\pm 6.3\end{array}$ & $\begin{array}{r}146.31 \\
\pm 3.73\end{array}$ & $\begin{array}{r}72.73 \\
\pm 0.53\end{array}$ \\
\hline & $\begin{array}{c}5.0 \mathrm{mg} / \mathrm{rat} \\
+ \\
0.5 \mathrm{mg} / \mathrm{kg}\end{array}$ & $\begin{array}{r}234.7 \\
\pm 9.2\end{array}$ & $\begin{array}{r}158.1 \\
\pm 9.4\end{array}$ & $\begin{array}{r}71.35 \\
\pm 0.31\end{array}$ \\
\hline
\end{tabular}

1 Values represent standard deviations of the mean.

$2 a^{+}$content is significantly higher in the gland of rats treated with the IPR-reserpine combination than in those of animals :reated with reserpine alone or with IPR alone. The higher dose of reserpine $(5.0 \mathrm{mg} / \mathrm{kg} \cdot \mathrm{day})$ produces an increase in the $\mathrm{Ca}^{+}$. sontent of the gland comparable to that induced by the $5 \mathrm{mg}$ $\mathrm{kg}$-day dose of IPR, but the higher dose of IPR $(5 \mathrm{mg} / \mathrm{rat} \cdot \mathrm{day})$ results in a significantly higher glandular $\mathrm{Ca}^{+}$content; (2) the increase in protein content is comparable after the two doses of IPR and the two lower doses of reserpine (0.0.5 and $0.5 \mathrm{mg} /$ $\mathrm{sg}$. daty) but is significantly greater $(P<0.0(15)$ after the higher lose of reserpine (5.0 $\mathrm{mg} / \mathrm{kg} \cdot \mathrm{day}$ ) and after combined IPReserpine treatment, regardless of the dose of IPR used in the sombined drug treatment. The glandular protein content in rats reated with a $0.5 \mathrm{mg} / \mathrm{kg}$-day dose of reserpine plus a $5 \mathrm{mg} /$ $\mathrm{kg} \cdot \mathrm{day}$ dose of IPR is significintly higher than that of the glands of rats treated with each individual dose alone. This indicates that, as in the case of $\mathrm{Ca}^{++}$. the effect of the combined drugs on glandular protein is greater than the individual effect of each drug.

Table 2 illustrates other characteristics of the resting (unstimulated) gland of the drug-treated rats. The percentage of water content of the gland was similar in all groups of animals. The average gland weight was significantly lower in reserpine-treated animals than in the other two groups of drug-treated animals. When the gland weight/body weight (GW/BW) ratios are compared, the higher dose of IPR $(5.0 \mathrm{mg} / \mathrm{rat} \cdot$ day $)$ induces a significant increase in this ratio when compared to that in animals treated with reserpine alone or with the smaller dose of IPR (5.0) $\mathrm{mg} / \mathrm{kg} \cdot \mathrm{day})$. This ratio is also significantly higher in rats treated with a combination of $I P R$ and reserpine, with the highest ratio observed in those rats treated with a $0.5 \mathrm{mg} / \mathrm{kg}$. day dose of reserpine plus a $5.0 \mathrm{mg} / \mathrm{rat}$ - day dose of IPR. Although the GW/ IBW ratio is higher after treatment with the IPR-reserpine combination. the values for gland weight alone suggest that reserpine reduces the hypertrophy induced by IPR.

\section{RESPONSE TO STIMULATION}

The secretory response from the gland of animals treated with a combination of IPR (5.0) $\mathrm{mg} / \mathrm{kg}$ - day) and reserpine ( $19.5 \mathrm{mg} /$ $\mathrm{kg}$-dity) wats assessed in terms of the volume and the composition of silfia secreted in response to stimulation with pilocarpine and with isoproterenol. Results are shown in Figures 1-t which illustrate the salivary $\mathrm{Ca}^{++}$and protein concentrations in relation to the rate of salivary flow. Figure 1 shows the Cat" concentrations of saliva obtained after pilocarpine stimulation. The shaded area in these figures represents the limits of normal concentrations in control saliva within $\pm 1 \mathrm{SI}$ ) of the mean. ( $\mathrm{a}^{+}$concenirations are higher than normal at low rates of salivary flow, but show some scatter at flow rates between 30 and $80 \mathrm{mg} / \mathrm{min} \times \mathrm{g}$ wet weight. Protein concentrations, on the other hand, are higher throughout the range of salivary flows obtained in these experiments (Fig. 2).

After stimulation with a secretory dose of IPR, saliva from the treated animals was grossly turbid and had the composition shown in Figures 3 and 4 . A significant increase in the $C^{+a^{+}}$and protein concentrations of saliva from the animals treated with the drug combination is illustrated in these figures. The highest

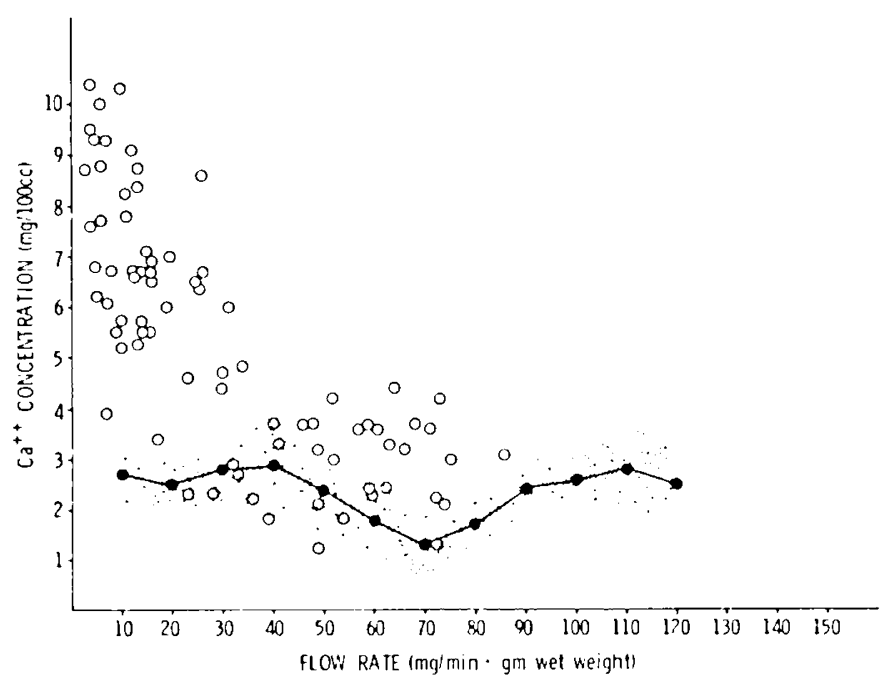

Fig. 1. Relationship between Ca1 ${ }^{++}$concentration and ratte of salivary flow in submaxillary saliva of rats treated with a combination of isoproterenol and reserpine. Salivary secretion was elicited by intraperitoneal injection of pilocarpine. The shaded area represents mean control values $\pm 1 \mathrm{SI}$ ) from the mean. (): values obtained in the treated animats.

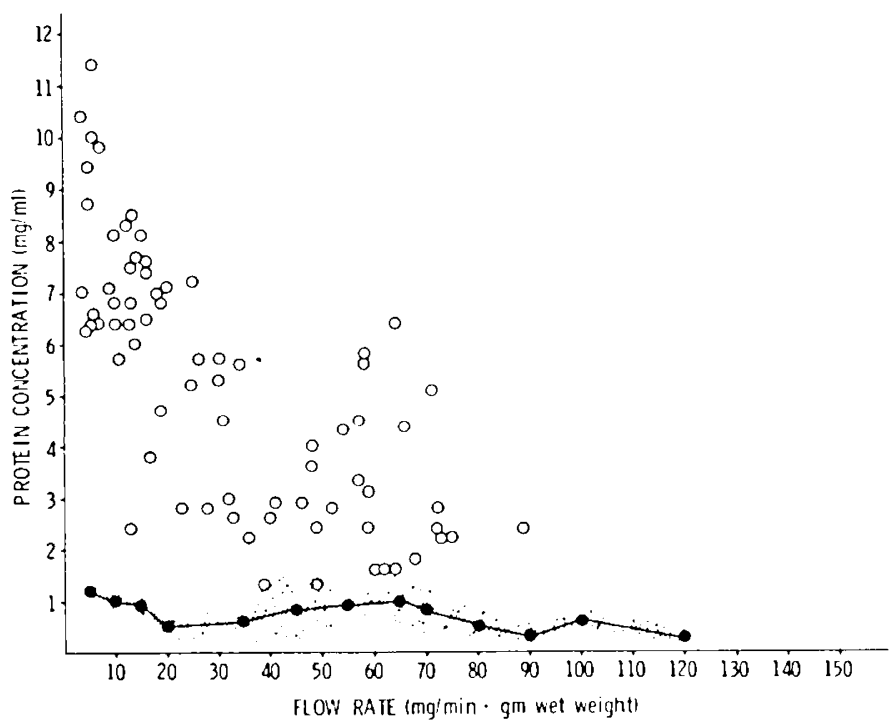

Fig. 2. Relationship between protein concentration in submaxillary saliva of rats treated with a combination of isoproterenol and reserpine obtained after stimulation with pilocarpine. Symbols and other pertinent data as in Figure 1. 


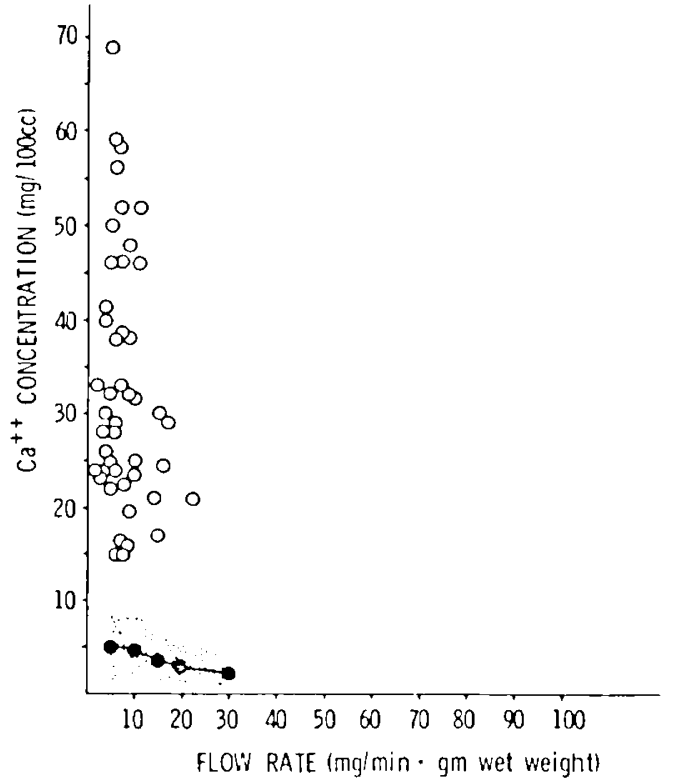

Fig. 3. $\mathrm{Ca}^{+4}$ concentration as a function of flow rate in submaxillary saliva of rats treated with a combination of isoproterenol and reserpine after stimulation with intraperitoneal isoproterenol. Symbols are the same as in Figure 1. Number of experiments: control rats $=22$, treated rats $=18$.

Ca" concentrations were between 60 and $70 \mathrm{mg} / \mathrm{l}(90 \mathrm{ml}$ and the highest protein concentrations were approximately $90 \mathrm{mg} / \mathrm{ml}$.

The secretory response to pilocarpine and to IPR is further illustrated in Table 3. The total volume of saliva secreted and the maximum flow rate attained after either type of stimulation were redeced in the animals treated with the drug combination when compared with the corresponding values in untreated controls. However, the total protein secreted and the amount of protein secreted per gof wet weight were markedly elevated not only in comparison to control rats but also, in the casce of IPR stimulation. to rats treated with reserpine alone (17).

The wet tissue composition was analyzed for the submaxillary gland of rats trated with a combination of IPR and reserpine after stimulation with the two secretagogues and is illustrated in Table t. Of the two secretagogues. IPR resulted in a significant decrease in the $\mathrm{Ca}^{++}$and protein contents of the submaxillary gland. This effect correlates with the high salivary concentrations of $\mathrm{Ca}^{++}$and protein observed after this secretagogue, in contrast to the much smaller effect of pilocarpine on these two salivary components.

\section{MORPIOLOGY}

The effect of the combined IPR-reserpine treatment on the morphology of the resting submaxillary gland is shown in Figure 5. Acinar elements appeared completely tilled with secretory material which, in contrast to that of reserpine-treated rats (16). appeared granulated. There was an increased granularity in the granular tubules and the presence of intraductal precipitates. Acinar glycoproteins showed an increased basophilia. After stimulation with pilocarpine, there was no change in the acinar elements and a slight reduction in the granularity of the tubules (Fig. 6). In contrast, IPR stimulation caused a marked depletion of the acinar cells, which appeared vacuolated. The granular tubules were also depleted of granules and some also appeared vacuolated. Secretory material was evident in the lumen of most ducts.

\section{DISCUSSION}

The $\mathrm{Ca}^{++}$concentrations of submaxillary salivat $(3,6,14)$ have been found to be elevated consistently in patients with cystic fibrosis. Increasing the $\mathrm{Ca}^{++}$levels in submaxillary saliva from normal individuals changes its appearance and electro phoretic pattern to that of CF saliva, and certain types of salivary glycoproteins, when present in high concentrations, combined with $\mathrm{Ca}^{++}$to form a reversible precipitate (12). Small molecular weight glycoproteins in saliva are aggregated by additional $C^{*}{ }^{*}$ (4) and elevated $\mathrm{Ca}^{+}$levels in submaxillary saliva of $\mathrm{CF}$ patient may be responsible for the formation of hydroxyapatite crystal. (2). Increased $\mathrm{Ca}^{++}$concentrations have also been found in the submaxillary gland and saliva of experimental animal modely developed by the chronic administration of either isoprotereno: or of reserpine to rats $(9,15,17,18)$.

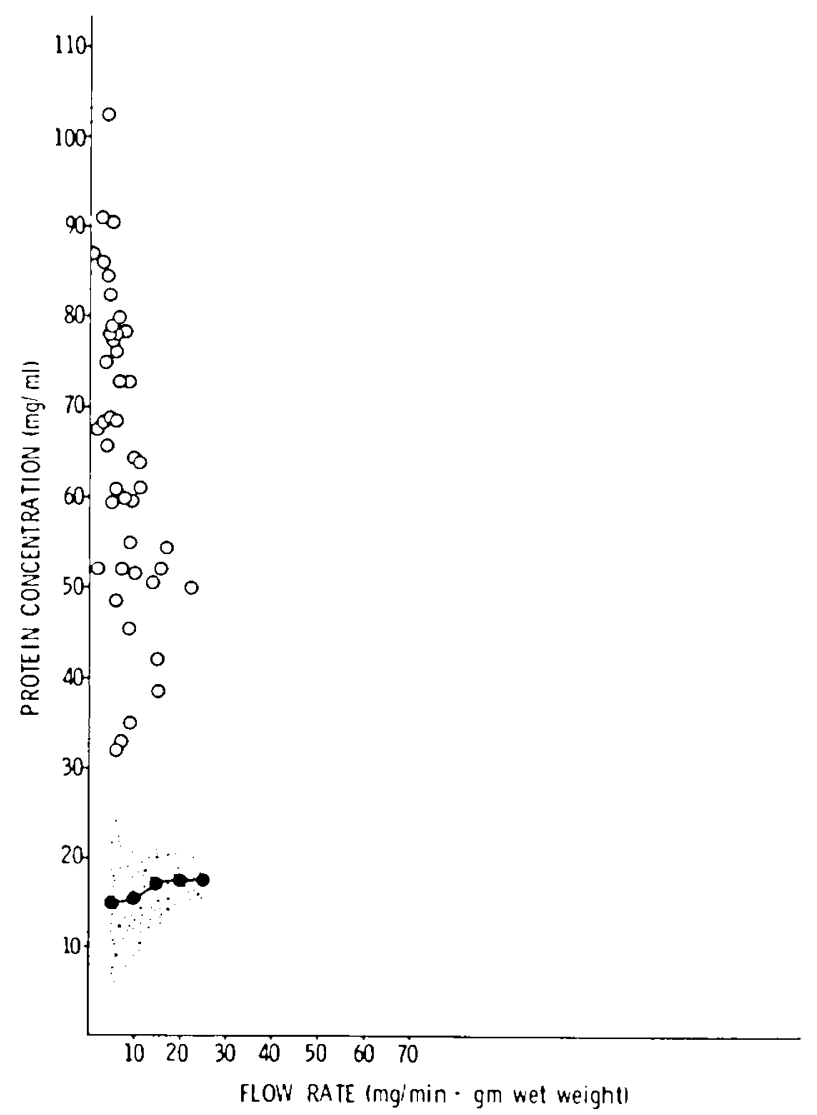

Fig. 4. Protein concentration as a function of flow rate in submaxiblars sativa of rats treated with a combination of isoproterenol and reserpince after stimulation with intraperitoneal isoproterenol. Symbols and other data as in Figure 3.

Table 3. Secrotory response and protein output

\begin{tabular}{|c|c|c|c|c|c|}
\hline Secrelagogue & Type of animal & $\begin{array}{l}\text { Maxi- } \\
\text { mum } \\
\text { flow } \\
\text { ratc. } \\
\text { mg/min } \\
\times g\end{array}$ & $\begin{array}{l}\text { Total } \\
\text { volume } \\
\text { of sit- } \\
\text { liva se- } \\
\text { crefed. } \\
\text { mg }\end{array}$ & $\begin{array}{l}\text { Total pro- } \\
\text { tein sc- } \\
\text { creted. } \mu !\end{array}$ & $\begin{array}{l}\text { Protedin } \\
\text { se- } \\
\text { creted/ } \\
\text { mg wet } \\
\text { wt }\end{array}$ \\
\hline \multirow[t]{2}{*}{ Pilocarpinc } & Control & 140 & $\begin{array}{l}1.024 \\
\pm 962\end{array}$ & $\begin{array}{l}996 \\
\pm 74=\end{array}$ & $\begin{array}{r}3.9 \\
\pm 10.3=\end{array}$ \\
\hline & IPR-RI:S & 88 & $\begin{array}{r}335 \\
\pm 25\end{array}$ & $\begin{array}{l}1.609 \\
\pm 109\end{array}$ & $\begin{array}{r}6.7 \\
\pm 0.5\end{array}$ \\
\hline \multirow[t]{2}{*}{ IPR } & Control & 36 & $\begin{array}{r}188 \\
\pm 18\end{array}$ & $\begin{array}{l}2.6 .35 \\
\pm 178\end{array}$ & $\begin{array}{r}14.9 \\
\pm 1.3\end{array}$ \\
\hline & IPR-RES & 21 & $\begin{array}{r}1.31 \\
\pm 7\end{array}$ & $\begin{array}{l}8.605 \\
\pm 424\end{array}$ & $\begin{array}{l}34.16 \\
\pm 4.24\end{array}$ \\
\hline
\end{tabular}

IPR: isoproterenol; RES: reserpine.

"Vilues represent standard deviations of the mean. 
Table 4. Calcium and protein contents of stimulated submaxillary gland (we't tissuce)

\begin{tabular}{|c|c|c|c|c|}
\hline Treatment & Stimulation & $n$ & $\mathrm{Ca}^{+}+$ & Protein \\
\hline $\begin{array}{l}\text { PR (5.0 } \mathrm{mg} / \mathrm{kg})+ \\
\text { reserpine }(1) .5 \mathrm{mg} /\end{array}$ & Pilocarpine & 30 & $\begin{aligned} & 0.937 \\
+ & 0.0114^{1}\end{aligned}$ & $\begin{array}{l}127.2 \\
\pm 2.8^{1}\end{array}$ \\
\hline $\mathrm{kg})$ & lsoproterenol & 26 & $\begin{array}{r}0.458 \\
\pm(0.019\end{array}$ & $\begin{array}{l}114.1 \\
\pm 4.1\end{array}$ \\
\hline
\end{tabular}

1 Values represent standard deviations of the mean.

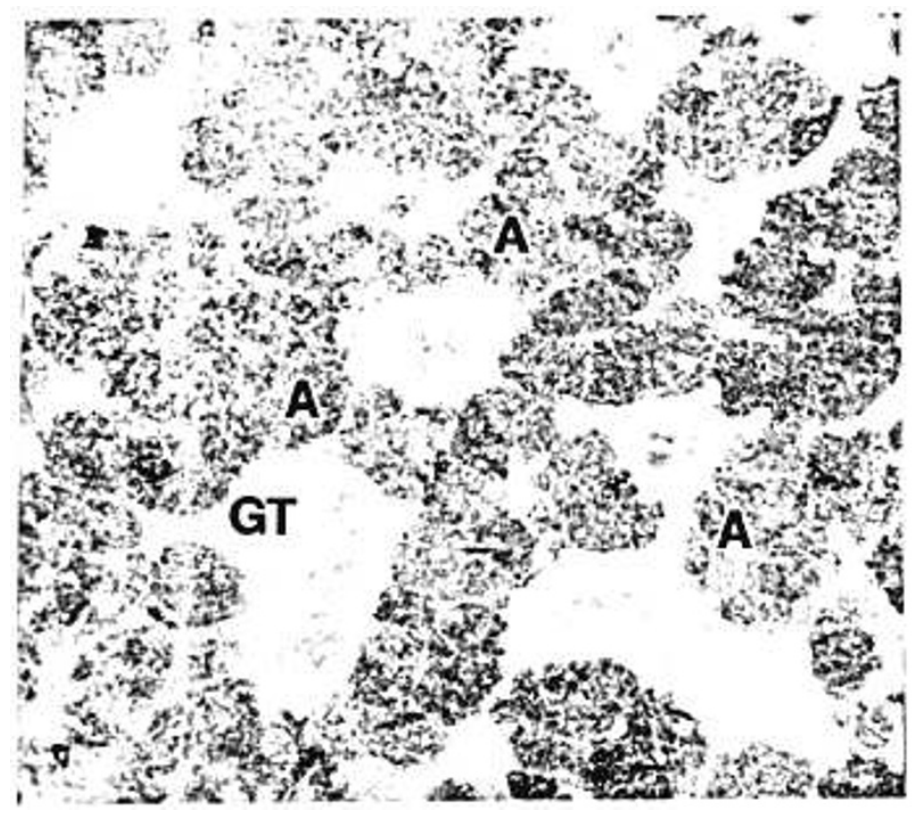

Fig. 5. Morpholegy of the resulting (unstimulated) submixillary gland of rats treated with a combination of isoproterenol and reserpinc. Note the meous acini $(A)$ filled with a fincly granular secretion and the presence of some granules in convoluted granular tubules $(G T)$. Alcian blue-periodic acid-Schiff stain, $\times 250$.

On the basis of this evidence, the results of the present experiments are significant in that they show that the effects of IPR and of reserpine on submaxillary gland $\mathrm{Ca}^{+}{ }^{+}$are dose-dependent and, furthermore, ssmergistic. The extremely high $\mathrm{Ca}$ " concentrations obtained after combined IPR-reserpine treatment have important implications in some aspects of the secretory physiology of the submaxillary gland. First, it appears from previous and from the present findings that procedures which increase glandular Ca" consistently reduce the secretory response to secretagogues $(18,19)$, as evidenced by decreased flow rates and total salivary volumes. The mechanism underlying this effect can not be ascertained on the basis of presently available evidenee. but may be related to $\mathrm{Ca}^{++}$effects on membrane permeability and therefore, on the ion fluxes that oceur upon stimulation. Secondly, since $C^{\prime}$ " has been shown to affect the transductal transport of monovalent ions in the rat submaxillary gland (20). the elevated $\mathrm{Ca}^{++}$concentrations found in the saliva of the treated animals can alter this transport and result in abnormal salivary cation concentrations. Finally, by enhanced binding to salivary mucoproteins, the increased $C{ }^{t+}$ produced by the combined drug treatment can alter their physicochemical propertices and, conseguently, their releatse from the secretory cells and their subseguent behavior within the salivary ducts. Recently. Ca" has been shown to modify an intestinal epithelial mucin, rendering it less hodrated and soluble and more granular (11). A similar effect on submaxillary glycoproteins could explain the increased granularity of acinar cells and the formation of intraductal precipitates that were obsersed in the present experiments. Pretreatment with reserpine has been shown to caluse the format- tion of an aggregate of soluble submaxillary glycoproteins and to alter their interaction in the presence of $\left(a^{+}+(21)\right.$.

These effects of $\mathrm{Ca}^{++}$on glandular secretory activity and composition can be relevant to the pathogenesis of the secretory abnormalities observed in the submaxillatry gland of CF patients. An clevated $\mathrm{Ca}^{+}$content in this gland could explain the secretion of excess $\left(a^{++}\right.$in saliva $(3,6,1+)$, the reduced salivary volumes reported in some studies (6, 22), and the progressive obstruction of ducts by the formation of insoluble precipitates (8). Increased $\mathrm{Ca}^{+}$concentrations can also have implications in

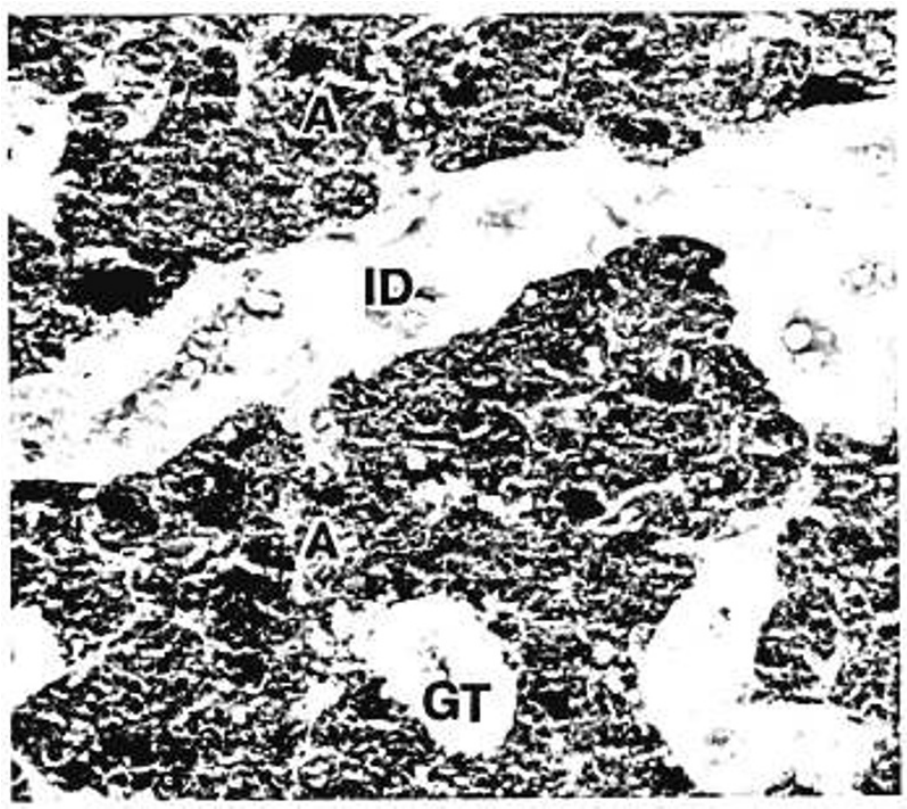

Fig. 6. Morphology of the submaxillary gland in rats treated with a combination of isoproterenol and reserpine $90 \mathrm{~min}$ after a pilocarpine secretory stimulus. The mucous acini $(A)$ are still filled with finely granular matcrial and there are increased amounts of intraductal material $(I D)$. Ciranularity in the granular ducts $(G T)$ is somewhat decreased. Alcian bluc-periodic acid-Schiff stain, $\times 250$.

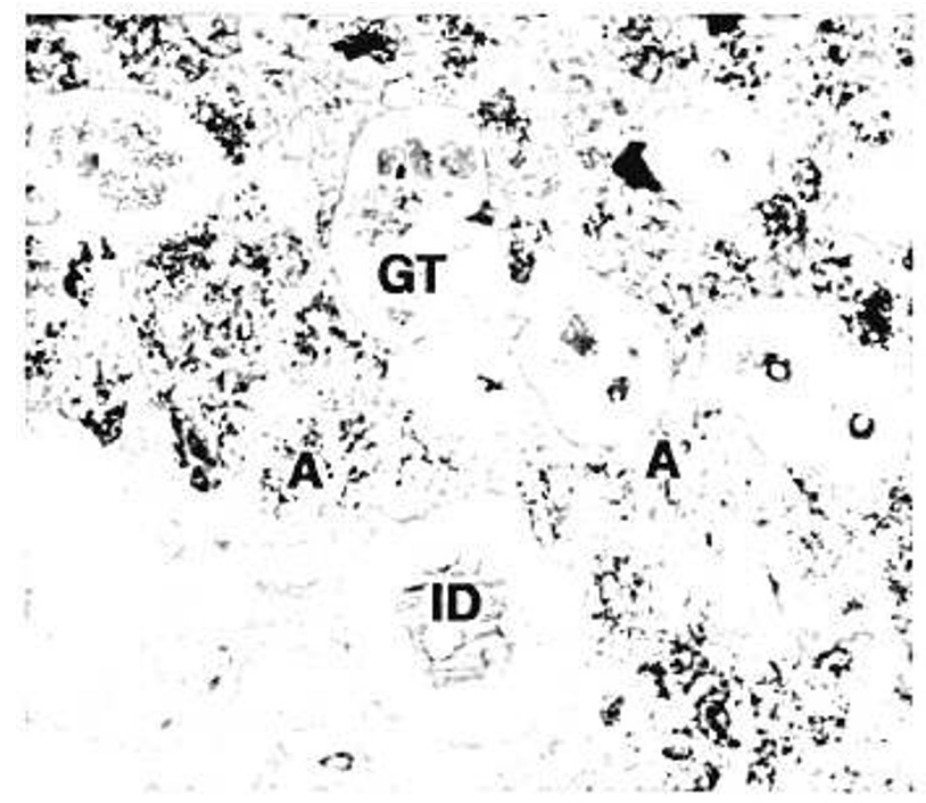

Iig. 7. Morphology of the submaxillary gland of rats treated with a combination of isoproteremel and reserpine 9() min after stimulation with isoproterenol. The mucous acini $(A)$ are depleted of secretory material. There is abundant intraductal material $(I D)$ and granules are evident in the gramular tubules $(G T)$. 
the production of cilioinhibitory effects by secretions from the $\mathrm{CF}$ patient $(1,5)$ and from the experimental animal models $(1$. 17).

In addition to the effects on Ca ${ }^{*}$. our results demonstrate that IPR and reserpine also increase glandular protein, the latter in a dose-dependent fashion similar to its effect on glandular $\mathrm{Cat}^{+}$. They also indicate that the effect is synergistic, as in the case of $\mathrm{Ca}^{+}$. When the wo drugs are administered in the manner described in these experiments. IPR has been previously shown to increase protein synthesis in the submaxillary gland (10), and reserpine directly stimulates the accumulation of trichloroacetic acid-soluble glycoproteins in this tissue (22). In addition to these effects on the amount of glandular protein. treatment with the IPR-reserpine combination results in cualitittive alterations of submaxillary glycoproteins, as suggested by the increased batsophilia of acinar cells. An increased number of sialic acid residues in the carbohydrate components of submaxillary glycoproteins could account for the increased basophilia and generate additional binding sites for the increased $\mathrm{Ca}^{++}$. This effect is most likely the result of a specifie action of reserpine. which has been shown to increase the sialic acid content of the submaxillary gland (22) and to cause structural changes in submaxillary glycoproteins (21). The reserpine effect on protein accumulation probably involves, in addlition, an inhibition of secretory activity and therefore, of protein release. secondary to depletion of sympathetic neurotransmitter (18). The inhibition of the secretory activity is supported by the finding that reserpine partially prevented the glandular enlargement induced by IPR administration (Table 2)

As a corollary of the marked effects on glandular composition. salivary $C{ }^{+*}$ and protein are markedly clevated in the animals treated with the IPR-reserpine combination, particularly after at secretory dose of IPR. In addition, stimulation with this secretagogue produced marked changes in the morphologic appearance of the gland and caused a parallel decrease in glandular $\mathrm{Ca}^{*}$ and protein (Table 4). These findings suggest that most of the increase in glandular protein induced by the combined drug treatment involved secretory proteins, although IPR alone also enhances the synthesis of structural protein. and that most of the increased $\mathrm{Ca}^{+}$"was bound to the secretory protein. In gencrall, the results of the present experiments provide the hasis for

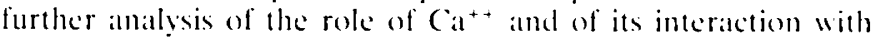
secretory macromolecules in the pathogenesis of secretory abnormalities such as those seen in the submaxillary gland of $\mathrm{C} F$ paticnts.

\section{CONCIUSION}

The effects of isoproterenol and of rexerpine on $\mathrm{Ca}^{++}$and protein in the rat submaxillary gland were investigated in experiments involving the chronic administration of graded doses of the two drugs, either alone or in combination. Results indicate that. individually. both drugs produce a dose-dependent increase in glandular Cat $^{+}$and that reserpine also causes a dosedependent increase in glandular protein. When the two drugs are administered in combination, furthermore, their individual offects become synergistic and the increase in glandular ( $a^{*}$ and protein are greater than those produced by either drug alone. These changes in glandular composition are accompanied by marked changes in glamdular morphology, including the accumulation of a basophilic. gramular material in acinar cells and the formation of intraductal precipitates. Submaxillary saliva from rats treated with the drug combination has markedly clevated $\mathrm{Ca}^{++}$and protein concentrations, particularly after IPR stimulation, and is reduced in volume. These results indicate that combined administration of IPR and reserpine induces both quantitatice and qualitative changes in submaxillary glycoproteins which. together with a marked drug-induced increase in glandular (at + results in alterations in the glandular secretors response and in the physiocochemical behavior of secretory macromolecules. It is speculated that a similar combination of pathephysiologic events. either in whole or in part, may explain the secretory disturbance in the submaxillary gland of $\mathrm{CF}^{\mathrm{p}}$ paticnts.

\section{REFERIN(TS ANI) NOTES}

1. Adhead, P. B... Martines, J. R., Kilhurn, K. H., and Hess, R. A.: Ciliar inhibition and axonemal microtubule alterations in fresh water muscle. Ann. N. Y. Acidd. Sci., 253: 192 (1975).

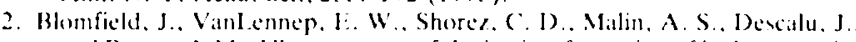
and Brown. J. M.: Ultrastructure of the in vitroformation of hedroxyapatite in submanditular saliva of children with custic fibrosis. Arch. Oral Biol.. 19 $1153(1474)$

3. Blomfield, J., Warton, K. L., and Brown. J. M.: Flow rate and inorganic components of submandibular saliva in crstic fibrosis. Arch. Dis. (hildhood. 48: $267(196,3)$

4. Boat. T. F. Wieman, U. N.. and Pallavicini. J. C.: Purification and properties of the calcium-precipitable protein in submaxillary saliva of normat and cystic fibrosis subjects. Pediat. Res., s: 5.31 (1974).

5. Bowman, B. H. Lockhart, L. H., and Mlecombs, M. L.: ()yster ciliart inhibition be custic fibrosis factor. Science, 164: 325 (1969).

6. Chernick. W. S., and Barbero. G. J.: Studiew on human tracheobronchial and submaxillary secretions in normal and pathephysiological conditions. Ann. N. Y. Acad. Sci. toto: 698 (1963).

7. Conover, J., Bogart, B. Conad, E.., and Gaterlan, P.: Alered ciliated tracheal cxplant function by Ca-ionophore. Cystic Fibrosis Club Abstacts. XVll Annual Meeting. Sit. Louis, 1976 p. 9

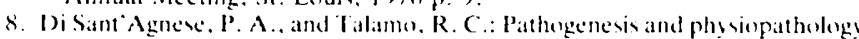

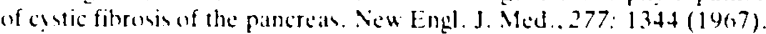

9. Dresbach. R. H.: liffect of isoproterenol on calcium, protein and electrolstes of rat submaxillary gland. Proc. Soc. Exp. Biol. Med., /26: 279 (1967).

10. Lihfors, T., and Barha, T.: The effect of joproterenol on protein synthe is in rat submandibular gland. Lath. Insest., 24: 197 (1971)

11. Forstner, J. F., and Forstner. (i. C.: Effect of $\mathrm{Ca}^{*}$ on intestinal mucin: implications for enstic fibrosis. Pediat. Res.. 10: 6019 (1976).

12. Gugler, E. C.. Pallavicini. J. ( ... Swerdlow, H., and D) Sant-Agnese. P.: The role of calcium in submaxillaty saliva of patients with estic fibrosis. J. Pediat. 7 l: $5 \times 5(1967)$

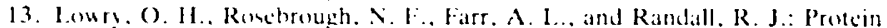
meisurement with the folin phenol reagent. J. Biol. Chem., 19.3: 26.5 (1951).

14. Mandel. J. D., Kutsher, A. Denning, C. R. Thempson. R. H. and Zegarclli. E. V.: Salivary studien in cy vic fihrosis. Amer. J. Dis. (hild.. 11.3: 4.31 (1967).

15. Manges. J. A. McSherry. N. R. Bente. P. J.. and Spock. A.: Studies on the pathegeness of enstic fibrosis: The joproterenol treated rat as an experimental model. In: D). Lawson: Proceedings of the Fifth International (ystic librosis Conference, pp. 25-3.t (C)stic Fibrosis Trust. Iomdun. 1969)

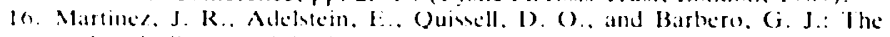
chronically reserpinied rat as a pensible model for cestic fibrois. 1. Submaxillary gland morphology and ultrastructure. Pediat. Res., $4: 46.3$ (1975).

17. Martince, J. R. Awheat, P. ('. ()uissell, D). ()., and Barbero, G. J.: The chronically reserpinized rat as a possible model for cystic fibrosis. II. Combposition and cilioinhibitory effects of submasillary saliva. Pediat. Res.. 9: $470(1975)$.

18. Martince, J. R.. (Ouincll. D). O., Wood, D). I... and Giles. 11.: Abnormal ectetory respone to paras mpathomimetic and sompathominetic stimulation from the submaxillary gland of rats treated with reserpine. J. Pharmatcol. Exp. Ther.. 194: $38+(1975)$

19. Schneser. C. A.: Saliwary gland changes after incproterenol-induced enlargement. Amer. J. Phusiol.. 2013: 232 (1962)

211. Schneyer. L. H.: Effect of calcium on Na. K trampent by perfued main duct of rat submaxillary gland. Amer. J. Phyviol. 220: $82 \mathrm{i}(1974)$.

21. Taylor, P. W.. Jr.. O Kecfe. P. R.. and Titus, F. O.: Evidence for structural changes in submaxillary gland glscoproteins its at direct effect of reserpine [Abur.|. Fed. Proc.. 27: 7019)(19606).

22. Tator. P. W.. Jr.. Richardom, K. C.. Rodd. P. M., and Titu. 1.. A ncw effect of reserpine: Accumulation of glycoprotein in the submasillary glath J. Pharmacol. Ixp. Ther., 156: $483(1967)$

23. Corning Scientific lnstruments, Medficld Mass.

24. The atuthors wish to express their appreciation w I) S. S. Spicer of the Medical University of South Carolina for his help in the morpholengic anpect of this study.

25. In the course of this work. Mr. Werol was supported by Student Irainceship from the Cestic Fihrosis Foundation and the Nattonal Foundation.

26. Dr. J. R. Martince is a recipient of a Research Scholar Award from the Cystic Fibrosis Foundation

27. This research as supported by grants from the cistic Fibrosis Foundation and the National Foundation.

28. Requests for reprints should be addressed to: J. R. Martinez, M. I).. Depart ment of Child Health. University of Missouri. School of Medicine. Columbia, Mo. 6.5201! (USA)

29. Received for publication August ". 1976.

31). Accepted for puthlication October s. 1976 